\title{
Controls on fire activity over the Holocene
}

\author{
S. Kloster, T. Brücher, V. Brovkin, and S. Wilkenskjeld \\ Land in the Earth System, Max Planck Institute for Meteorology, Hamburg, Germany \\ Correspondence to: S. Kloster (silvia.kloster@mpimet.mpg.de)
}

Received: 1 October 2014 - Published in Clim. Past Discuss.: 11 November 2014

Revised: 30 March 2015 - Accepted: 10 April 2015 - Published: 27 May 2015

\begin{abstract}
Changes in fire activity over the last 8000 years are simulated with a global fire model driven by changes in climate and vegetation cover. The changes were separated into those caused through variations in fuel availability, fuel moisture or wind speed, which react differently to changes in climate. Disentangling these controlling factors helps in understanding the overall climate control on fire activity over the Holocene.

Globally the burned area is simulated to increase by $2.5 \%$ between 8000 and 200 cal yr BP, with larger regional changes compensating nearly evening out on a global scale. Despite the absence of anthropogenic fire ignitions, the simulated trends in fire activity agree reasonably well with continentalscale reconstructions from charcoal records, with the exception of Europe. For some regions the change in fire activity is predominantly controlled through changes in fuel availability (Australia monsoon, Central America tropics/subtropics). For other regions changes in fuel moisture are more important for the overall trend in fire activity (North America, SubSaharan Africa, Europe, Asia monsoon). In Sub-Saharan Africa, for example, changes in fuel moisture alone lead to an increase in fire activity between 8000 and $200 \mathrm{cal} \mathrm{yr} \mathrm{BP,}$ while changes in fuel availability lead to a decrease. Overall, the fuel moisture control is dominating the simulated fire activity for Sub-Saharan Africa.

The simulations clearly demonstrate that both changes in fuel availability and changes in fuel moisture are important drivers for the fire activity over the Holocene. Fuel availability and fuel moisture do, however, have different climate controls. As such, observed changes in fire activity cannot be related to single climate parameters such as precipitation or temperature alone. Fire models, as applied in this study, in combination with observational records can help in under-
\end{abstract}

standing the climate control on fire activity, which is essential to project future fire activity.

\section{Introduction}

Fires appeared on Earth soon after the onset of terrestrial plants and are an integral part of the Earth system (Bowman et al., 2009). Fires form an important natural disturbance process affecting vegetation distribution and structure (Scheiter and Higgins, 2009). Presently an area of between 301 and 377 Mha burns annually (Giglio et al., 2013). Fires impact the climate through various processes, such as changes in surface properties and emissions of trace gases and aerosols into the atmosphere (Randerson et al., 2006; Ward et al., 2012; Keywood et al., 2013). At the same time, fires are controlled by climate (Westerling, 2006; Harrison et al., 2010). Ongoing anthropogenic climate change is likely to alter fire activity (Scholze et al., 2006; Pechony and Shindell, 2010; Kloster et al., 2012). An analysis of palaeorecords on fire activity can improve our understanding of the climate control on fire activity, which will be essential to project future fire activity and climate change.

Microscopic charcoal pieces in sediments have been related to fire history for different parts of the world going back in time for thousands of years (Patterson et al., 1987; Whitlock and Millspaugh, 1996; Scott, 2002). The Global Charcoal Database (Power et al., 2010) has collected over 400 radiocarbon-dated charcoal records covering the late Quaternary. This database and associated updates have been used in various studies to improve our understanding of fire history (Power et al., 2007; Marlon et al., 2008, 2009).

The charcoal database provides information about changes in past fire activity. Relating those to changes in climate is often not straightforward. Fire activity is affected by 
changes in climate by directly altering lightning ignition sources (Price and Rind, 1994) and fuel moisture (Dwyer et al., 2000; Westerling et al., 2003) and indirectly through changes in fuel availability and vegetation distribution (Westerling et al., 2003; Martin Calvo et al., 2014). The importance of these controlling factors for fire activity varies across climate regimes. In dry regions fire activity is typically limited by fuel availability, but fuel moisture is sufficiently low to lead to successful fire ignitions. Under moist climate conditions fuel availability is sufficiently guaranteed, but fuel moisture is often too high to allow for fires to spread (van der Werf et al., 2010). Consequently, climate change will impact fire activity differently in different climate zones and fire regimes.

Here, we investigate the climate control on fire activity over the Holocene by disentangling the controls via fuel availability, fuel moisture and wind speed within a fire model (Arora and Boer, 2005; Kloster et al., 2010) embedded in a global land vegetation model (JSBACH; Raddatz et al., 2007; Brovkin et al., 2009; Reick et al., 2013). We simulate fire activity for the period 8000 cal yr BP until 200 cal yr BP with the land vegetation model coupled to a climate model of intermediate complexity (CLIMBER-2; Petoukhov et al., 2000; Ganopolski and Rahmstorf, 2001). Fire activity has been observed to change over this period as a result of climate change (Carcaillet et al., 2002; Marlon et al., 2013). With the help of a global model we want to understand the reason for those changes.

\section{Method}

This study applies the coupled climate-carbon cycle model CLIMBA (Brücher et al., 2014). CLIMBA consists of the Earth system model of intermediate complexity CLIMBER2 (Petoukhov et al., 2000; Ganopolski and Rahmstorf, 2001) and JSBACH (Raddatz et al., 2007; Brovkin et al., 2009; Reick et al., 2013), which is the land surface and vegetation model of the MPI Earth System Model (MPI-ESM; Giorgetta et al., 2013). CLIMBER is applied with a resolution of $51^{\circ}$ (longitude) by $10^{\circ}$ (latitude) to simulate atmosphere and land processes, while JSBACH runs at a higher resolution $\left(3.75^{\circ} \times 3.75^{\circ}\right)$ including a daily cycle. JSBACH and CLIMBER-2 are coupled following Kleinen et al. (2010).

The simulations are set up in a similar way to Brücher et al. (2014). The base climate is represented by 50 years extracted from a MPI-ESM CMIP5 simulation, representative of the climate of the early industrial period (1850-1899). CLIMBER-2-simulated climate anomalies are added to this 50 year spanning annually varying base climate. The resulting climate is used as forcing for JSBACH. This approach is required as CLIMBER-2 does not simulate year-to-year climate variability, which is critical for simulating land and vegetation dynamics in JSBACH. Unlike in Brücher et al. (2014) we did not randomly choose a year out of the 50 -year base climate but instead applied a constant base climate cycle, i.e. every 50-year cycle followed the same sequence. As a result the data presented here do not have any year-to-year variability when smoothed over 50 years or a multiple thereof.

The default JSBACH model was extended with a processbased fire model (Arora and Boer, 2005; Kloster et al., 2010; Krause et al., 2014) with updates according to $\mathrm{Li}$ et al. (2012). The fire model calculates the total fire occurrence probability as the product of three probability functions representing the availability of biomass, fuel moisture and ignition potential. The fire then spreads as a function of wind speed and soil moisture. Fuel availability is simulated as a function of aboveground biomass. Soil moisture is used as a surrogate for fuel moisture. Lightning ignitions are prescribed from a satellite-based climatology (Cecil et al., 2012) extended by a latitudinal dependency of the cloud-to-ground vs. intra-cloud lightning fraction (Price and Rind, 1994). Human ignitions are not accounted for. With poorly constrained data on human fire interaction over the Holocene, we do not see any means to include those in the present study. However, fire models that do not explicitly account for human ignition can still reproduce the main features of the fire regime even in areas in which many fires are set by humans as has been shown by Prentice et al. (2011). Humans often set fire in regions that are fire-prone; as such, human ignitions tend to preempt, rather than augment, the natural fire regime (Prentice et al., 2011).

Soil moisture, aboveground biomass and wind speed control the burned area in the fire model. A high soil moisture lowers the fire occurrence probability and the overall fire spread. The model assumes that a fire gets extinguished above a moisture of 0.35 . A high aboveground biomass ensures a high fire occurrence probability. The fire model scales the fire probability constrained by fuel availability linearly between a lower aboveground biomass amount of $200 \mathrm{gC} \mathrm{m}^{2}$ and an upper amount of $1000 \mathrm{gC} \mathrm{m}^{2}$. A high wind speed increases the fire spread and the burned area. An increase in wind speed from 15 to $20 \mathrm{~km} \mathrm{~h}^{-1}$, for example, results in an increase in the fire spread rate of $25 \%$ based on observations (Arora and Boer, 2005).

For this study we performed several experiments to disentangle the control of these single forcings on the simulated fire activity over the Holocene (Table 1).

In experiment FMW, all parameters controlling fire activity in the model are varying with time, i.e. the full set of forcing is applied and the simulated burned area represents fire activity over the Holocene. This experiment serves as reference for the factor experiments. In the factor experiments, one single forcing factor varies over time. The others are prescribed continuously over the simulation period as a constant 50-year cycle, representative of 8000 cal yr BP conditions (7999 to $7900 \mathrm{cal}$ yr BP), and are taken from the output of the reference experiment FMW.

In experiment $\mathrm{M}$, only the soil moisture is varying with time; fuel availability and wind speed are kept constant over 
Table 1. Experiments performed for this study that keep single forcing factors controlling simulated fire activity constant or varying over the simulation period 8000 to $200 \mathrm{cal} \mathrm{yr} \mathrm{BP}$.

\begin{tabular}{llll}
\hline & Fuel availability & Fuel moisture & Wind speed \\
\hline F & varying & constant & constant \\
M & constant & varying & constant \\
W & constant & constant & varying \\
FMW & varying & varying & varying \\
\hline
\end{tabular}

time. In experiment F, only the fuel availability is varying with time; soil moisture and wind speed are kept constant. In experiment $\mathrm{W}$, only the wind speed is varying with time; soil moisture and fuel availability are kept constant.

\section{Results}

At 200 cal yr BP, on average 528 Mha burn annually (see also Brücher et al., 2014), which is on the higher end of presentday satellite-based observed estimates (Giglio et al., 2013). The simulation presented does not, however, account for the human-fire impact and uses dynamically simulated natural vegetation cover not including agricultural areas. As such, the simulations are not directly comparable to present-day satellite-based observations. Overall, the model does capture the major burning regions in Sub-Saharan Africa, southeastern Asia, northern Australia and parts of North and South America (Fig. 1a).

Globally the change in burned area is small over the Holocene, with a slight increase in fire activity simulated between 8000 and 200 cal yr BP $(+14$ Mha $(+2.5 \%))$. Regionally, however, the simulation shows areas with pronounced increases (e.g. central Africa, parts of Australia, and southern Europe) as well as decreases (e.g. in northern North America and in South America), which nearly even out on a global scale (Fig. 1b). Brücher et al. (2014) showed that the simulated climate over the Holocene is characterised for the northern tropics by an intensified and northward-shifted monsoon system which leads to a widespread greening between 8000 and $4000 \mathrm{cal} \mathrm{yr} \mathrm{BP,} \mathrm{in} \mathrm{line} \mathrm{with} \mathrm{previous} \mathrm{findings}$ (Claussen, 1997; Brovkin et al., 2002; Prentice et al., 1992). Between $20-30^{\circ} \mathrm{S}$, drier conditions are simulated when zonally averaged during the period 8000 to $6000 \mathrm{cal} \mathrm{yr} \mathrm{BP}$. This is a result of drier conditions in southern Africa (caused by the northward-shifted monsoon system), drier conditions in Amazonia and a small increase in precipitation in Australia. These changes in climate alter fire activity over the Holocene as shown by Brücher et al. (2014). Here we further disentangle what caused these changes in fire activity.

Similar to Brücher et al. (2014), we analyse the transient evolution of the burned area between 8000 and 200 cal yr BP averaged over continental-scale regions. Figure 2 and Table 2 depict the changes in burned area for the control simulation in which the fire submodel is driven with varying fuel availability, moisture and wind speed (experiment FMW); in other words, all parameters impacting fire activity are varying and the simulation is identical to the one presented in Brücher et al. (2014). The single-factor experiments, in which only one parameter impacting fire activity is varying over time, are shown as well in Fig. 2 and are summarised in Table 2. The regions are chosen as analogues to Marlon et al. (2013) to facilitate comparison with changes in fire activity reported in the charcoal database. The fire activity is reported in $z$ scores in the charcoal database. $Z$ scores are a standardised measure frequently used by the palaeofire community to compare aggregated values of past fire activity. They are, however, not a quantitative measure and therefore cannot be related to absolute changes (Power et al., 2010).

Brücher et al. (2014) compared in detail simulated burned area and charcoal data reported as $z$ scores. For the same regions as presented here, Brücher et al. (2014) found rank correlation between simulated burned area and charcoal data reported as $z$ scores between 0.32 and 0.66 , with the highest correlation found for North America, which is also the region with the most charcoal data available (up to 83 charcoal sites). This comparison is done on a regional average even though the charcoal data are very site-specific and some regions are only represented by a few charcoal sites; for example, Sub-Saharan Africa has only three sites. The coarse resolution of the climate model, however, does not allow for a site-specific evaluation as the single site conditions (precipitation, temperature, etc.) cannot be explicitly resolved, whereas region-specific characteristics are in general expected to be captured.

In the following we will focus on the impact of fuel availability and moisture on fire activity over the Holocene for the single regions. Results are presented relative to the 8000 cal yr BP state (7900-7999), which is identical for all simulations. Absolute changes for burned area and a number of external forcing factors (precipitation, surface temperature, gross primary productivity, biomass carbon, soil carbon) are presented Fig. 2 in the Supplement of Brücher et al. (2014).

What all regions have in common is that changes in wind speed between 8000 and 200 cal yr BP do not significantly impact the fire activity, as the simulated wind speed changes over the Holocene are very small (less than $0.1 \%$ for the regions analysed). Therefore, the wind speed control on fire activity will not be further discussed for this study.

For the Asian monsoon region (Fig. 2a), the simulated burned area increases between 8000 and 200 cal yr BP by around $9 \%$. For the same time period, the charcoal data report an increase in fire activity as well. The increase in simulated burned area is primarily driven by reduced moisture in response to decreases in precipitation (15\%). For the Asian monsoon region, precipitation decreases by $17 \%$, which is equal to $\sim 150 \mathrm{~mm} \mathrm{yr}^{-1}$. Changes in fuel availability alone have only a minor impact on fire activity for this region (1\%). 


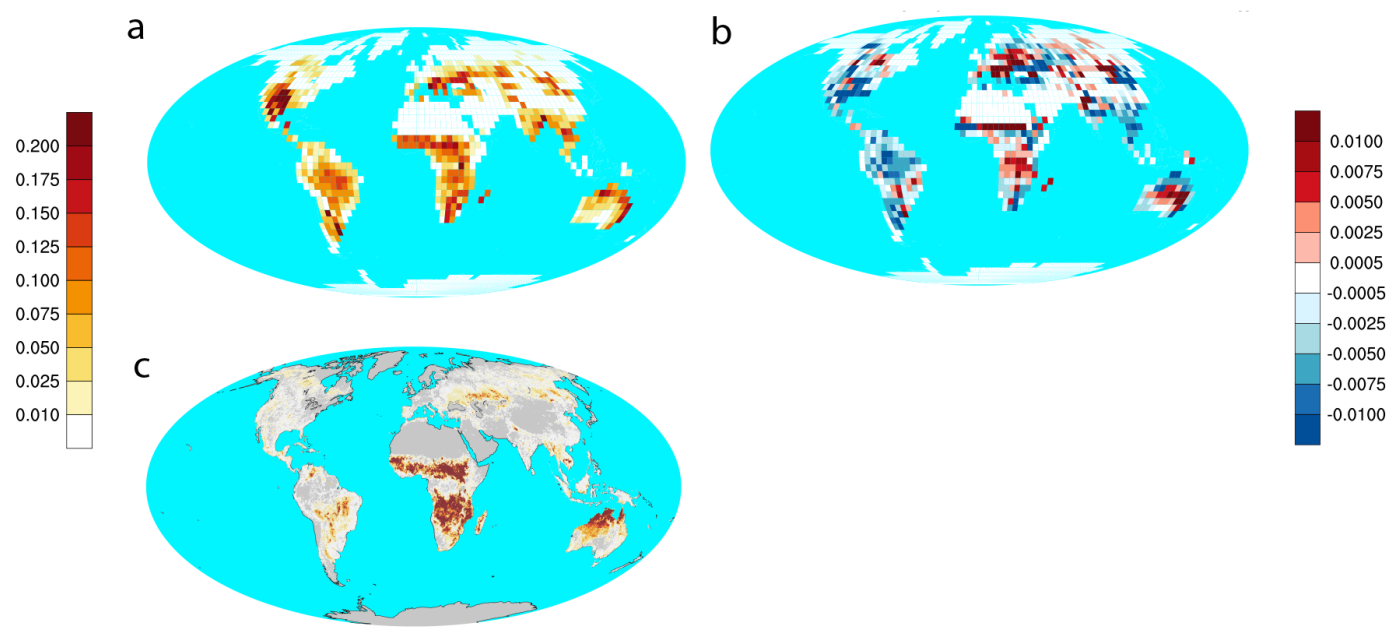

Figure 1. Simulated annual burned fraction of grid cell area $\left[\mathrm{m}^{2} \mathrm{~m}^{-2}\right]$ of natural fire activity for 8000 cal yr BP (a) and differences between 8000 and $200 \mathrm{cal}$ yr BP (7900-7999 minus 100-199) (b). Panel (c) shows the burned area based on present-day satellite observations as reported in GFED4 (Giglio et al., 2013).

Table 2. Difference in burned area between 200 and 8000 cal yr BP (100-199 minus 7900-7999) relative to the 8000 cal yr BP state in [\%] for different regions and experiments (F: fuel availability varying; M: moisture varying; W: wind speed varying; FMW: fuel availability, moisture and wind speed varying - control simulation). Regions are chosen according to Marlon et al. (2013). Significant values (confidence level higher than $95 \%$ determined with a Student $t$ test) are shown in bold.

\begin{tabular}{lrrrr}
\hline & $F$ & $\mathrm{M}$ & $\mathrm{W}$ & FMW \\
\hline North America & 1.87 & $\mathbf{6 . 0 6}$ & -0.1 & $\mathbf{4 . 6 8}$ \\
Europe & $\mathbf{- 1 0 . 0 5}$ & $\mathbf{- 2 5 . 2 3}$ & -1.24 & $\mathbf{- 2 2 . 7 5}$ \\
Asia monsoon & 0.97 & $\mathbf{1 4 . 7 0}$ & 0.23 & $\mathbf{9 . 3 8}$ \\
Central America tropics/subtropics & $\mathbf{4 . 0 9}$ & 1.00 & -0.29 & $\mathbf{4 . 1 7}$ \\
Sub-Saharan Africa & $\mathbf{4 . 7 5}$ & $\mathbf{4 . 1 5}$ & -1.84 & $\mathbf{- 2 . 2 5}$ \\
Australia monsoon & $\mathbf{9 . 1 8}$ & 0.09 & 1.28 & $\mathbf{7 . 7 4}$ \\
\hline
\end{tabular}

For North America (Fig. 2b) the burned area increases between 8000 and 200 cal yr BP $(+4 \%)$, which agrees with the increase reported in the charcoal database. Changes in fuel availability alone lead to a small increasing trend $(+2 \%)$, while changes in moisture dominate the overall increase in fire activity $(+6 \%)$. A lower fire activity between 7000 and 5000 cal yr BP is noticeable, which is in accordance with a simulated drop in temperature within that period $(\sim-5 \%$, which is equal to $\sim 0.20^{\circ} \mathrm{C}$ ).

For Sub-Saharan Africa (Fig. 2c) the simulated burned area decreases between 8000 and 3000 cal yr BP $(-2 \%)$ and remains almost constant afterwards. In contrast, the charcoal data indicate lower fire activity during the period 8000 to 2000 cal yr BP compared to the period 2000 to $200 \mathrm{cal}$ yr BP. The decrease in simulated burned area is dominated by the biomass control on fire activity, which leads to a decrease in burned area between 8000 and $200 \mathrm{cal}$ yr BP $(-5 \%)$. This trend fits to with an increase in desert extent between 8000 and 200 cal yr BP by $\sim 17 \%$ and a decrease in precipitation by $6 \%$, which is equal to $\sim 50 \mathrm{~mm} \mathrm{yr}^{-1}$ ).

For the Central America tropics (Fig. 2d) the burned area shows an increase between 8000 and $200 \mathrm{cal} \mathrm{yr} \mathrm{BP}(+4 \%)$. Similar findings are reported in the charcoal data, with somewhat lower levels between 4000 and 200 cal yr BP compared to the period 6000 to $4000 \mathrm{cal} \mathrm{yr} \mathrm{BP}$. Overall the trend in fire activity is dominated by a fuel availability control $(+4 \%)$, which scales linearly with an increase in available biomass $(+3 \%)$. Changes in fire activity due to moisture are smaller $(+1 \%)$ and in line with the simulated small decrease in precipitation $\left(0.3 \%\right.$, which is equal to $\left.\sim 30 \mathrm{~mm} \mathrm{yr}^{-1}\right)$.

For Europe (Fig. 2e) the burned area decreases over the Holocene. In 200 cal yr BP the burned area is approximately $23 \%$ lower compared to 8000 cal yr BP. For the same time period the charcoal data show an increase in fire activity. The simulated changes in burned area for Europe can be largely explained by the moisture control on fire activity, while changes in fuel availability alone result in a smaller decrease ( -25 compared to $-10 \%$, respectively). Biomass decreases when averaged over Europe between 8000 and $200 \mathrm{cal}$ yr BP $(-3 \%)$, which is in line with the fuel-availability-driven trend in fire activity. Averaged over Europe, precipitation is increasing in accordance with a decrease in fire activity driven by changes in moisture. Europe is the only analysed region for which the simulated burned area and the charcoal data show opposite trends. One reason for this discrepancy might be the missing anthropogenic fire control in our simulations. Molinari et al. (2013) showed in a modelling study that increased fire activity during the mid- to late Holocene were primarily driven by changes in anthropogenic land cover, which we do not account for in our simulation.

For the Australia monsoon region (Fig. 2f) the burned area increases between 8000 and $200 \mathrm{cal} \mathrm{yr} \mathrm{BP}(+8 \%)$. The 
a) Asia Monsoon

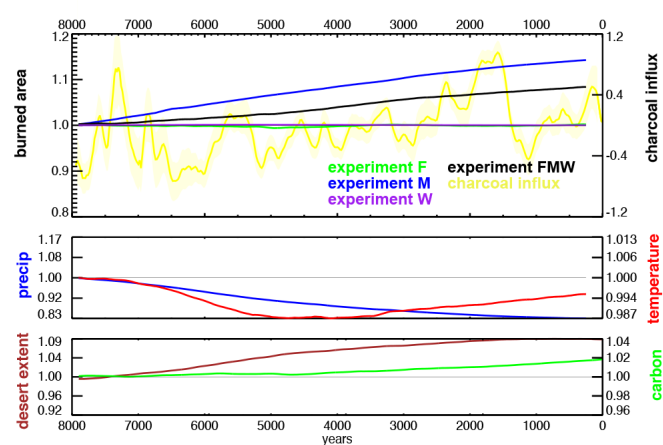

b) North America

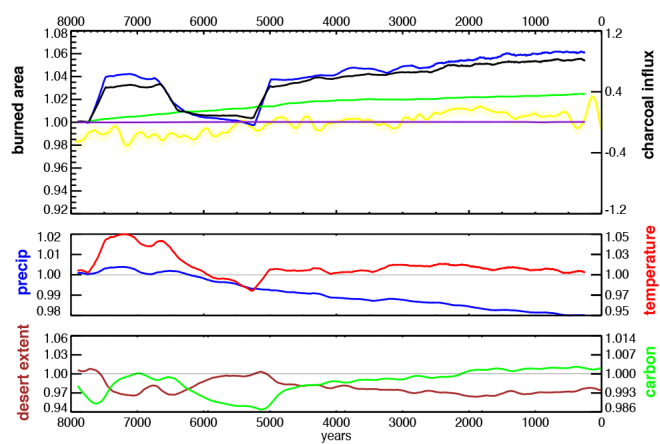

c) Sub-Saharan Africa

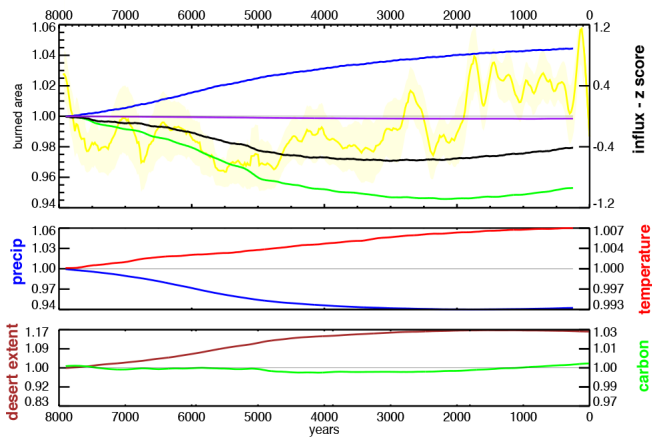

d) Central America Tropics

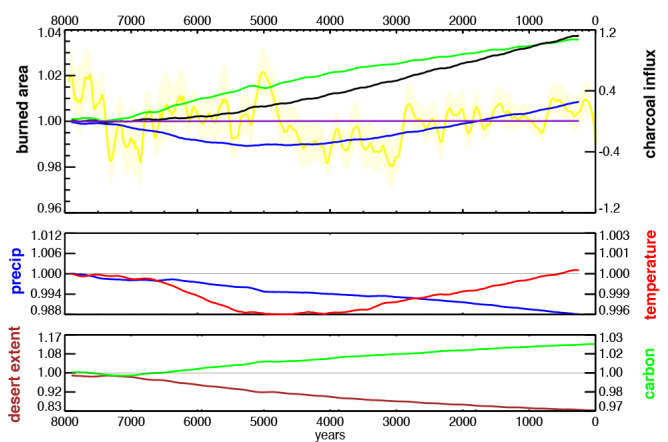

e) Europe

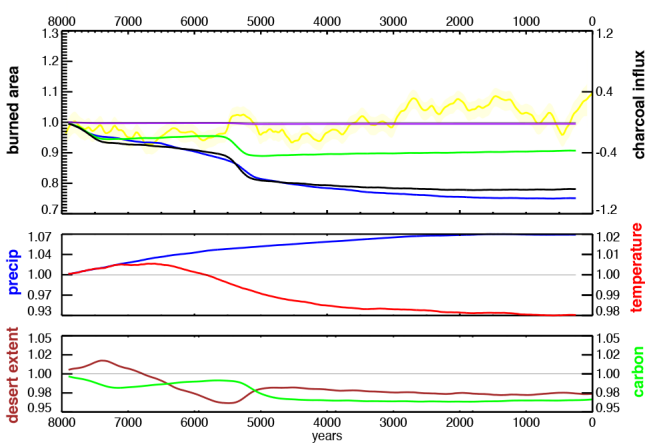

f) Australia Monsoon

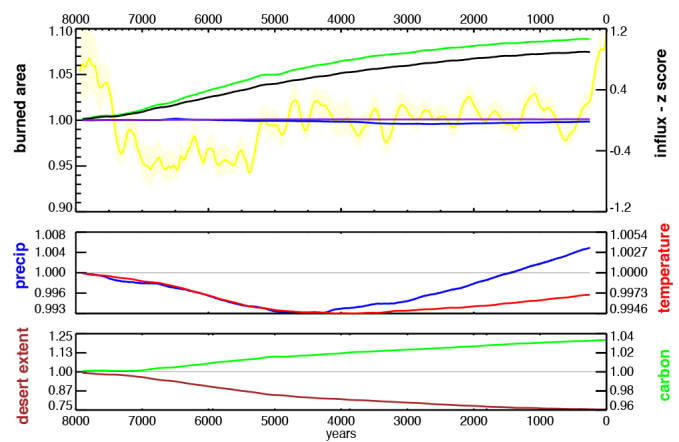

Figure 2. Transient changes in burned area between 8000 and $200 \mathrm{cal} \mathrm{yr} \mathrm{BP}$ averaged over continental-scale regions (upper panels) for the experiments: FMW (black), M (blue), F (green) and W (purple). The charcoal data are presented in yellow. The lower panels show changes in climate (precipitation (blue), surface temperature (red)) and vegetation state variables (land carbon storage (green), desert extent (brown)). The definition of the domains is taken from Marlon et al. (2013). Changes are normalised with respect to the 8000 cal yr BP state and smoothed with a 250-year running mean similar to Brücher et al. (2014) and Marlon et al. (2013). Absolute changes for burned area and a number of external forcing factors (precipitation, surface temperature, gross primary productivity, biomass carbon, soil carbon) are shown in Fig. 2 in the Supplement of Brücher et al. (2014).

charcoal data show a drop in fire activity between 8000 and $7000 \mathrm{cal} \mathrm{yr} \mathrm{BP}$, an increase up to $5000 \mathrm{cal} \mathrm{yr} \mathrm{BP}$, and constant fire activity thereafter. For this region the overall trend in burned area is to a large extent explained by changes in fuel availability $(+9 \%)$, whereas changes in moisture have no impact on fire activity averaged over the region.

Moisture, fuel availability and wind speed do not control the fire activity independently but interact with each other.
As such the system is non-linear, i.e. changes in burned area caused by changes in fuel availability, moisture and wind speed alone do not add to the changes in burned area which are simulated when fuel availability, moisture and wind speed are changed simultaneously. This is also reflected in the model simulations. For all regions we find negative synergies, i.e. the changes in burned area are smaller when driving factors are changed simultaneously (control simula- 
tion, experiment FMW) compared to adding the response of the individual experiments, in which only one forcing factor is changed at a time(adding the experiments $\mathrm{F}, \mathrm{M}$ and $\mathrm{W}$ ).

\section{Conclusions}

Globally the burned area is simulated to increase by $2.5 \%$ between 8000 and 200 cal yr BP. Regionally, however, the change in burned area is larger, with decreases and increases nearly evening out on a global scale.

While in some regions the burned area changes are predominantly controlled via changes in fuel availability (Australia monsoon, Central America tropics/subtropics), others are more strongly impacted via changes in fuel moisture (North America, Europe, Asia monsoon, Sub-Saharan Africa). Fuel availability and fuel moisture do, however, have different climate controls. While, for example, precipitation generally allows for the build-up of fuel load, it also increases fuel moisture, with both processes having opposite effects on fire occurrence, i.e. an increase in precipitation leads to an increase in burned area in regions in which fuel availability is the dominant controlling factor and decreases burned area in regions where fuel moisture is more important. In our analysis, we find, for example, that an increase in precipitation increases the burned area in Australia and decreases the burned area in Europe. As such, the present study clearly shows that the climate control on fire activity is difficult to assess from simple climate indices (such as temperature or precipitation) and palaeofire records alone as done previously (e.g. Marlon et al., 2008, 2009). Only more complex relationships that take into account more than one explaining climate variable might be suitable for interpretation of the climate control of past fire activity (Daniau et al., 2012). Consequently, estimates on future fire activity cannot only be based on, for example, temperature and precipitation trends derived from climate projections, as they require a more integrative approach. This could be based on process-based fire models that are evaluated against observations including charcoal data or more complex causal functional relationships derived from observations that will greatly benefit from a further extension of the charcoal database. Future fire activity, however, will be strongly anthropogenically disturbed in many parts of the world, which limits the applicability of relationships derived from past fire activity to future climate conditions. Changes in land use, urban settlement, human ignition and fire suppression will all impact fire activity and will most likely dominate the overall change in fire activity in many places in the world (Andela and van der Werf, 2014; Kloster et al., 2012). Nevertheless, understanding the climate control on fire activity is essential for management plan that aims for a sustainable future.

Fire models can help in understanding the climate control on past fire activity, as shown in this study. However, fire models are limited in their ability to reproduce global fire activity as they are built on a still incomplete process understanding on vegetation fire occurrence (Pfeiffer et al., 2013; Kloster et al., 2010; Pechony and Shindell, 2010). The human control on vegetation fires through fire ignition and fire suppression are controlled by population evolution and various socio-economic factors (Archibald et al., 2012), which are difficult to assess on a global scale. In this study we are therefore not able to account for human ignition. Lightning ignition are kept constant even though they are climatecontrolled (Price and Rind, 1994), but no data on lightning occurrence over the Holocene are available.

The most striking mismatch between simulated fire activity and fire activity derived from charcoal data is found for Europe, showing opposite trends in the simulation and the observations over the Holocene. While this might be a result of the model itself caused by a missing anthropogenic fire control, it might be also caused by uncertainties in the charcoal data or an averaging over large regions that include different fire regimes with different climate controls. Combining fire models and charcoal data more closely in future studies could help in overcoming the high uncertainties related to fire modelling as well as reconstructing fire activity from charcoal records.

The article processing charges for this open-access publication were covered by the Max Planck Society.

Edited by: C. Barbante

\section{References}

Andela, N. and van der Werf, G. R.: Recent trends in African fires driven by cropland expansion and El Niño to La Niña transition, Nature Clim. Change, 4, 791-795, 2014.

Archibald, S., Staver, A. C., and Levin, S. A.: Evolution of humandriven fire regimes in Africa, P. Natl. Acad. Sci. USA, 109, 847852, 2012.

Arora, V. K. and Boer, G. J.: Fire as an interactive component of dynamic vegetation models, J. Geophys. Res.-Biogeo., 110, G02008, doi:10.1029/2005JG000042, 2005.

Bowman, D. M. J. S., Balch, J. K., Artaxo, P., Bond, W. J., Carlson, J. M., Cochrane, M. A., D’Antonio, C. M., DeFries, R. S., Doyle, J. C., Harrison, S. P., Johnston, F. H., Keeley, J. E., Krawchuk, M. A., Kull, C. A., Marston, J. B., Moritz, M. A., Prentice, I. C., Roos, C. I., Scott, A. C., Swetnam, T. W., van der Werf, G. R., and Pyne, S. J.: Fire in the Earth System, Science, 324, 481-484, 2009.

Brovkin, V., Bendtsen, J., Claussen, M., Ganopolski, A., Kubatzki, C., Petoukhov, V., and Andreev, A.: Carbon cycle, vegetation, and climate dynammics in the Holocene: experiments with the CLIMBER-2 model, Global Biogeochem. Cy., 16, 86-1-8620, 2002.

Brovkin, V., Raddatz, T., Reick, C. H., Claussen, M., and Gayler, V.: Global biogeophysical interactions between forest and climate, Geophys. Res. Lett., 36, L07405, doi:10.1029/2009GL037543, 2009. 
Brücher, T., Brovkin, V., Kloster, S., Marlon, J. R., and Power, M. J.: Comparing modelled fire dynamics with charcoal records for the Holocene, Clim. Past, 10, 811-824, doi:10.5194/cp-10-8112014, 2014.

Carcaillet, C., Almquist, H., Asnong, H., Bradshaw, R. H. W., Carrión, J. S., Gaillard, M. J., Gajewski, K., Haas, J. N., Haberle, S. G., Hadorn, P., Müller, S. D., Richard, P. J. H., Richoz, I., Rösch, M., Sánchez Goñi, M. F., von Stedingk, H., Stevenson, A. C., Talon, B., Tardy, C., Tinner, W., Tryterud, E., Wick, L., and Willis, K. J.: Holocene biomass burning and global dynamics of the carbon cycle, Chemosphere, 49, 845-863, 2002.

Cecil, D. J., Buechler, D. E., and Blakeslee, R. J.: Gridded lightning climatology from TRMM-LIS and OTD: dataset description, Atmos. Res., 135-136, 404-414, doi:10.1016/j.atmosres.2012.06.028, 2014.

Claussen, M.: Modeling bio-geophysical feedback in the African and Indian monsoon region, Clim. Dynam., 13, 247-257, 1997.

Daniau, A. L., Bartlein, P. J., Harrison, S. P., Prentice, I. C., Brewer, S., Friedlingstein, P., Harrison-Prentice, T. I., Inoue, J., Izumi, K., Marlon, J. R., Mooney, S., Power, M. J., Stevenson, J., Tinner, W., Andrič, M., Atanassova, J., Behling, H., Black, M., Blarquez, O., Brown, K. J., Carcaillet, C., Colhoun, E. A., Colombaroli, D., Davis, B. A. S., D'Costa, D., Dodson, J., Dupont, L., Eshetu, Z., Gavin, D. G., Genries, A., Haberle, S., Hallett, D. J., Hope, G., Horn, S. P., Kassa, T. G., Katamura, F., Kennedy, L. M., Kershaw, P., Krivonogov, S., Long, C., Magri, D., Marinova, E., McKenzie, G. M., Moreno, P. I., Moss, P., Neumann, F. H., Norström, E., Paitre, C., Rius, D., Roberts, N., Robinson, G. S., Sasaki, N., Scott, L., Takahara, H., Terwilliger, V., Thevenon, F., Turner, R., Valsecchi, V. G., Vannière, B., Walsh, M., Williams, N., and Zhang, Y.: Predictability of biomass burning in response to climate changes, Global Biogeochem. Cy., 26, GB4007, doi:10.1029/2011GB004249, 2012.

Dwyer, E., Grégoire, J.-M., and Pereira, J.: Climate and vegetation as driving factors in global fire activity, in: Biomass Burning and its Inter-Relationships with the Climate System, edited by: Innes, J., Beniston, M., and Verstraete, M., 3, Adv. Glob. Change Res., Springer, the Netherlands, 171-191, 2000.

Ganopolski, A. and Rahmstorf, S.: Rapid changes of glacial climate simulated in a coupled climate model, Nature, 409, 153 158,2001

Giglio, L., Randerson, J. T., and van der Werf, G. R.: Analysis of daily, monthly, and annual burned area using the fourthgeneration global fire emissions database (GFED4), J. Geophys. Res.-Biogeo., 118, 317-328, 2013.

Giorgetta, M. A., Jungclaus, J., Reick, C. H., Legutke, S., Bader, J., Böttinger, M., Brovkin, V., Crueger, T., Esch, M., Fieg, K., Glushak, K., Gayler, V., Haak, H., Hollweg, H.-D., Ilyina, T., Kinne, S., Kornblueh, L., Matei, D., Mauritsen, T., Mikolajewicz, U., Mueller, W., Notz, D., Pithan, F., Raddatz, T., Rast, S., Redler, R., Roeckner, E., Schmidt, H., Schnur, R., Segschneider, J., Six, K. D., Stockhause, M., Timmreck, C., Wegner, J., Widmann, H., Wieners, K.-H., Claussen, M., Marotzke, J., and Stevens, B.: Climate and carbon cycle changes from 1850 to 2100 in MPI-ESM simulations for the Coupled Model Intercomparison Project phase 5, J. Adv. Model. Earth Syst., 5, 572-597, 2013.

Harrison, S., Marlon, J., and Bartlein, P.: Fire in the Earth System, in: Changing Climates, Earth Systems and Society, edited by: Dodson, J., International Year of Planet Earth, Springer, the Netherlands, 21-48, doi:10.1007/978-90-481-8716-4_3, 2010.

Keywood, M., Kanakidou, M., Stohl, A., Dentener, F., Grassi, G., Meyer, C. P., Torseth, K., Edwards, D., Thompson, A. M., Lohmann, U., and Burrows, J.: Fire in the air: Biomass burning impacts in a changing climate, Crit. Rev. Env. Sci. Tec, 43, 40-83, 2013.

Kleinen, T., Brovkin, V., von Bloh, W., Archer, D., and Munhoven, G.: Holocene carbon cycle dynamics, Geophys. Res. Lett., 37, L02705, doi:10.1029/2009GL041391, 2010.

Kloster, S., Mahowald, N. M., Randerson, J. T., Thornton, P. E., Hoffman, F. M., Levis, S., Lawrence, P. J., Feddema, J. J., Oleson, K. W., and Lawrence, D. M.: Fire dynamics during the 20th century simulated by the Community Land Model, Biogeosciences, 7, 1877-1902, doi:10.5194/bg-7-1877-2010, 2010.

Kloster, S., Mahowald, N. M., Randerson, J. T., and Lawrence, P. J.: The impacts of climate, land use, and demography on fires during the 21 st century simulated by CLM-CN, Biogeosciences, 9, 509-525, doi:10.5194/bg-9-509-2012, 2012.

Krause, A., Kloster, S., Wilkenskjeld, S., and Paeth, H.: The sensitivity of global wildfires to simulated past, present, and future lightning frequency, J. Geophys. Res.-Biogeo., 119, 312-322, 2014.

Li, F., Zeng, X. D., and Levis, S.: A process-based fire parameterisation of intermediate complexity in a Dynamic Global Vegetation Model, Biogeosciences, 9, 2761-2780, doi:10.5194/bg-9-27612012, 2012.

Marlon, J. R., Bartlein, P. J., Carcaillet, C., Gavin, D. G., Harrison, S. P., Higuera, P. E., Joos, F., Power, M. J., and Prentice, I. C.: Climate and human influences on global biomass burning over the past two millennia, Nat. Geosci., 1, 697-702, 2008.

Marlon, J. R., Bartlein, P. J., Walsh, M. K., Harrison, S. P., Brown, K. J., Edwards, M. E., Higuera, P. E., Power, M. J., Anderson, R. S., Briles, C., Brunelle, A., Carcaillet, C., Daniels, M., Hu, F. S., Lavoie, M., Long, C., Minckley, T., Richard, P. J. H., Scott, A. C., Shafer, D. S., Tinner, W., Umbanhowar, C. E., and Whitlock, C.: Wildfire responses to abrupt climate change in North America, P. Natl. Acad. Sci. USA, 106, 2519-2524, 2009.

Marlon, J. R., Bartlein, P. J., Daniau, A.-L., Harrison, S. P., Maezumi, S. Y., Power, M. J., Tinner, W., and Vanniére, B.: Global biomass burning: a synthesis and review of Holocene paleofire records and their controls, Quaternary Sci. Rev., 65, 5-25, 2013.

Martin Calvo, M., Prentice, I. C., and Harrison, S. P.: Climate vs. carbon dioxide controls on biomass burning: a model analysis of the glacial-interglacial contrast, Biogeosciences Discuss., 11, 2569-2593, doi:10.5194/bgd-11-2569-2014, 2014.

Molinari, C., Lehsten, V., Bradshaw, R. H. W., Power, M. J., Harmand, P., Arneth, A., Kaplan, J. O., Vanniére, B., and Sykes, M. T.: Exploring potential drivers of European biomass burning over the Holocene: a data-model analysis, Global Ecol. Biogeogr., 22, 248-1260, 2013.

Patterson, W. A. I., Edwards, K. J., and MacGuire, D. J.: Microscopic charcoal as a fossil indicator of fire, Quaternary Sci. Rev. 6, 3-23, 1987.

Pechony, O. and Shindell, D. T.: Driving forces of global wildfires over the past millennium and the forthcoming century, P. Natl. Acad. Sci. USA, 107, 19167-19170, 2010. 
Petoukhov, V., Ganopolski, A., Brovkin, V., Claussen, M., Eliseev, A., Kubatzki, C., and Rahmstorf, S.: CLIMBER-2: a climate system model of intermediate complexity. Part I: model description and performance for present climate, Clim. Dynam., 16, 1-17, 2000.

Pfeiffer, M., Spessa, A., and Kaplan, J. O.: A model for global biomass burning in preindustrial time: LPJ-LMfire (v1.0), Geosci. Model Dev., 6, 643-685, doi:10.5194/gmd-6-643-2013, 2013.

Power, M. J., Marlon, J., Ortiz, N., Bartlein, P. J., Harrison, S. P., Mayle, F. E., Ballouche, A., Bradshaw, R. H. W., Carcaillet, C., Cordova, C., Mooney, S., Moreno, P. I., Prentice, I. C., Thonicke, K., Tinner, W., Whitlock, C., Zhang, Y., Zhao, Y., Ali, A. A., Anderson, R. S., Beer, R., Behling, H., Briles, C., Brown, K. J., Brunelle, A., Bush, M., Camill, P., Chu, G. Q., Clark, J., Colombaroli, D., Connor, S., Daniau, A. L., Daniels, M., Dodson, J., Doughty, E., Edwards, M. E., Finsinger, W., Foster, D., Frechette, J., Gaillard, M. J., Gavin, D. G., Gobet, E., Haberle, S., Hallett, D. J., HIGUERA, P., Hope, G., Horn, S., Inoue, J., Kaltenrieder, P., Kennedy, L., Kong, Z. C., Larsen, C., Long, C. J., Lynch, J., Lynch, E. A., McGlone, M., Meeks, S., Mensing, S., Meyer, G., Minckley, T., Mohr, J., Nelson, D. M., New, J., Newnham, R., Noti, R., Oswald, W., Pierce, J., Richard, P. J. H., Rowe, C., Sánchez Goñi, M. F., Shuman, B. N., Takahara, H., Toney, J., Turney, C., UrregoSanchez, D. H., Umbanhowar, C., Vandergoes, M., Vannière, B., Vescovi, E., Walsh, M., Wang, X., Williams, N., Wilmshurst, J., and Zhang, J. H.: Changes in fire regimes since the Last Glacial Maximum: an assessment based on a global synthesis and analysis of charcoal data, Clim. Dynam., 30, 887-907, 2007.

Power, M. J., Marlon, J. R., Bartlein, P. J., and Harrison, S. P.: Fire history and the Global Charcoal Database: a new tool for hypothesis testing and data exploration, Palaeogeogr. Palaeocl., 291, 52-59, 2010.

Prentice, I. C., Cramer, W., Harrison, S. P., Leemans, R., Monserud, R. A., and Solomon, A. M.: Special paper: a global biome model based on plant physiology and dominance, soil properties and climate, J. Biogeogr., 19, 117-134, 1992.

Prentice, I. C., Kelley, D. I., Foster, P. N., Friedlingstein, P., Harrison, S. P., and Bartlein, P. J.: Modeling fire and the terrestrial carbon balance, Global Biogeochem. Cy., 25, GB3005, doi:10.1029/2010GB003906, 2011.

Price, C. and Rind, D.: The impact of a $2 \times \mathrm{CO}_{2}$ climate on lightning-caused fires, J. Climate, 7, 1484-1494, 1994.
Raddatz, T. J., Reick, C. H., Knorr, W., Kattge, J., Roeckner, E., Schnur, R., Schnitzler, K. G., Wetzel, P., and Jungclaus, J.: Will the tropical land biosphere dominate the climate-carbon cycle feedback during the twenty-first century?, Clim. Dynam., 29, 565-574, 2007.

Randerson, J. T., Liu, H., Flanner, M. G., Chambers, S. D., Jin, Y., Hess, P. G., Pfister, G., Mack, M. C., Treseder, K. K., Welp, L. R., Chapin, F. S., Harden, J. W., Goulden, M. L., Lyons, E., Neff, J. C., Schuur, E. A. G., and Zender, C. S.: The impact of boreal forest fire on climate warming, Science, 314, 1130-1132, 2006.

Reick, C. H., Raddatz, T., Brovkin, V., and Gayler, V.: Representation of natural and anthropogenic land cover change in MPI-ESM, J. Adv. Model. Earth Syst., 5, 1-24, doi:10.1002/jame.20022, 2013.

Scheiter, S. and Higgins, S. I.: Impacts of climate change on the vegetation of Africa: an adaptive dynamic vegetation modelling approach, Glob. Change Biol., 15, 2224-2246, 2009.

Scholze, M., Knorr, W., Arnell, N. W., and Prentice, I. C.: A climate-change risk analysis for world ecosystems, P. Natl. Acad. Sci. USA, 103, 13116-13120, 2006.

Scott, L.: Microscopic charcoal in sediments: quaternary fire history of the grassland and savanna regions in South Africa, J. Quaternary Sci., 17, 77-86, 2002.

van der Werf, G. R., Randerson, J. T., Giglio, L., Collatz, G. J., Mu, M., Kasibhatla, P. S., Morton, D. C., DeFries, R. S., Jin, Y., and van Leeuwen, T. T.: Global fire emissions and the contribution of deforestation, savanna, forest, agricultural, and peat fires (19972009), Atmos. Chem. Phys., 10, 11707-11735, doi:10.5194/acp10-11707-2010, 2010.

Ward, D. S., Kloster, S., Mahowald, N. M., Rogers, B. M., Randerson, J. T., and Hess, P. G.: The changing radiative forcing of fires: global model estimates for past, present and future, Atmos. Chem. Phys., 12, 10857-10886, doi:10.5194/acp12-10857-2012, 2012.

Westerling, A. L.: Warming and earlier spring increase Western US forest wildfire activity, Science, 313, 940-943, 2006.

Westerling, A. L., Gershunov, A., Brown, T. J., Cayan, D. R., and Dettinger, M. D.: Climate and wildfire in the Western United States, B. Am. Meteorol. Soc., 84, 595-604, 2003.

Whitlock, C. and Millspaugh, S. H.: Testing the assumptions of firehistory studies: an examination of modern charcoal accumulation in Yellowstone National Park, USA, The Holocene, 6, 7-15, 1996. 